\title{
Development of MISTION Software to Detect and Reduce Students' Misconception with Conceptual Change Text Strategy on Stoichiometry Materials
}

Rizky Amallia Prastika*, Sukarmin

Chemistry Department, Universitas Negeri Surabaya, Surabaya, 60231, Indonesia

\section{ARTICLE INFO}

\section{Article history:}

Received: 02 Jan 2021

Revised: 29 June 2021

Accepted: 02 July 2021

Published online: 24 July 2021

\section{Keywords:}

Misconception

Software

Conceptual Change Text

Stoichiometry

\begin{abstract}
A B S T R A C T
Misconceptions often occur, especially in chemical material like stoichiometry which are full of abstract concepts. The purpose of this study was to determine the feasibility of mistion software to detect and reduce misconceptions in stoichiometric material with conceptual change text strategy. This research was conducted using the Research and Development (R\&D) method with 15 students of SMAN 1 Gedangan as research subjects. Software is developed using Adobe Flash CS 6 with action script 3.0. The software's feasibility is viewed from the validity practicality, and effectiveness. The data analysis results show that 1) the software is very valid with the average result of content validation is $93.52 \%$, and the construct validation is $91.82 \%$. 2) The software is very practical, with an average result of student response questionnaires is $95.28 \%$ and supported with the average result of student observations is 85\%. 3) Software is effective with the average result of misconception shift for sub-concept basic chemical law is $77.27 \%$ with effective category, sub-concept of reaction equation is $85.05 \%$ with very effective category, and sub-concept of mole is $73,72 \%$ with effective category. Based on the result, we can conclude that mistion software is feasible to detect and reduce students' misconception.
\end{abstract}

\section{Introduction}

Chemistry is a study about the composition, structure, and properties of the material to the atomic scale and molecular changes and interaction in matter formation (Putri et al., 2020). The concept in chemistry is abstract, which means that the content being studied does not appear concretely (Sadiqin et al., 2017). One of the most basic and important materials in chemistry is stoichiometry. Stoichiometry is the basic material about quantitative relationships in chemistry. It 
studies the basic law of chemistry, molar mass, mole, percent yield, etc. These concepts are abstract, tiered, and interrelated so that they cause students to experience difficulties in understanding stoichiometry (Sutinah \& Sigit, 2018).

Concepts and phenomena in stoichiometry should be explained to students through levels of representation. Chemistry will be easy to understand if represented in three levels of representation, namely macroscopic, submicroscopic, and symbolic (Adadan, 2013). Chemistry learning in schools generally emphasizes explanations at the macroscopic and symbolic levels so that students' understanding at the submicroscopic level is reduced. The submicroscopic level is a key factor in understanding chemistry concept (Mashami et al., 2014). It means that the inability to represent the submicroscopic aspect can hinder students' ability to solve problems related to the macroscopic and symbolic levels.

The misconception is defined as a concept that a person believes in and a stable cognitive structure but not suitable with scientific concepts agreed by the experts (Alhinduan et al., 2016). Concepts in chemistry are interrelated, so the understanding level of one concept affects others. Misconceptions on one material will have an impact on learning difficulties in other materials. Stoichiometry is a difficult material because of the many abstract concepts and concepts related to the ratio or proportion of reactants and products in chemical calculations, giving rise to misconceptions about the stoichiometric concept (Nikmawati et al., 2019). It is supported by various study that shows many students experience misconceptions on stoichiometric material (Djarwo, 2020; Wiwiana et al., 2020; Wulandari \& Rusmini, 2020)

Identifying student misconceptions is very important for the student learning process in the future. One way to find out the misconception is by using a diagnostic test. A diagnostic test is used to determine the weakness of students' understanding of a concept. One of the diagnostic tests that have been developed in Indonesia is a three-tier test. The three-tier test is a multiple-choice test consisting of three levels of matter where the first is a simple multiple-choice question, the second is the possibility of choosing the answer at the first level, and the third is the belief of the answer at the first level (Anintia et al., 2017). The three-tier test instrument has the advantage of being able to distinguish between misconceptions and lack of understanding of concepts or not knowing concepts through the level of confidence of students' answers, making it accurate in detecting misconceptions (Peşman \& Eryilmaz, 2010).

There are several methods and strategies used to eliminate misconceptions and promote the process of changing conceptions, one of which is the use of Conceptual Change Text (CCT). A conceptual change text is a text used to support students' conceptual change by identifying student misconceptions, denying these misconceptions, and introducing scientific concepts that can explain the phenomena presented (Kurniasih, 2013). The four stages in this strategy are (1) showing students' conceptions, (2) creating cognitive conflicts, (3) equilibrating processes, and (4) reconstructing students' concepts (Sendur \& 
Toprak, 2013). The stage of making conceptual conflicts and equilibration is the stage where students can experience a change in concept through a cognitive accommodation process.

Interactive multimedia can be used as a tool to convey and improve concepts on stoichiometric material. The use of interactive multimedia can be a powerful solution to reduce misconceptions in students. Interactive multimedia is an alternative effort that teachers can choose to present chemical concepts at the macroscopic, microscopic, and symbolic level because interactive multimedia combines animation, images, text, audio, and video (Fitria et al., 2016). The application of multimedia technology in the learning process provides a concrete experience and helps the students integrate the experience (Made Rajendra \& Made Sudana, 2017). In the course of practice, the use of multimedia technology application can help students to understand in depth the material being taught, as well as overcoming the limitations of space, time, and equipment (Made Rajendra \& Made Sudana, 2017).

The misconception in stoichiometry needs to be reduced to achieve optimal learning objectives. Based on the background described above, the purpose of this research is to know the feasibility of mistion software to detect and reduce students' misconceptions with conceptual change text strategy on the subject matter of stoichiometry based on validity, practicality, and effectivity of the software.

\section{Methodology}

\section{Place, Time, and Subject Study}

The research was conducted in Senior High School in Sidoarjo, from August 2020 to December 2020. The subject study is 15 student eleventh-grade Mathematics and Natural Science in the odd semester 2020-2021 who has been received stoichiometric materials.

\section{Study Instrument}

The feasibility of the software is viewed from the aspects of validity, practicality, and effectiveness. The validity of the software is known based on the content and construct validity sheet instruments. The software's practicality is known based on the student response questionnaire instrument and is supported by the student activity observation instrument. The effectiveness of the software is known based on the results of shifting student misconceptions.

\section{Data Analysis}

This research was conducted using Research and Development or (R\&D) method. Research and Development $(\mathrm{R} \& \mathrm{D})$ is a research method to develop a new product or improve an existing product (Sugiyono, 2017). The steps in the R\&D method 
are analysis of potentials and problems, data collection, product design, design validation, design revision, product trial, product revision, usage trials, further product revisions, and mass production manufacturing. However, in this research, the stage was only carried out until the product trial stage. The schematic of R\&D method steps is presented in Figure 1.

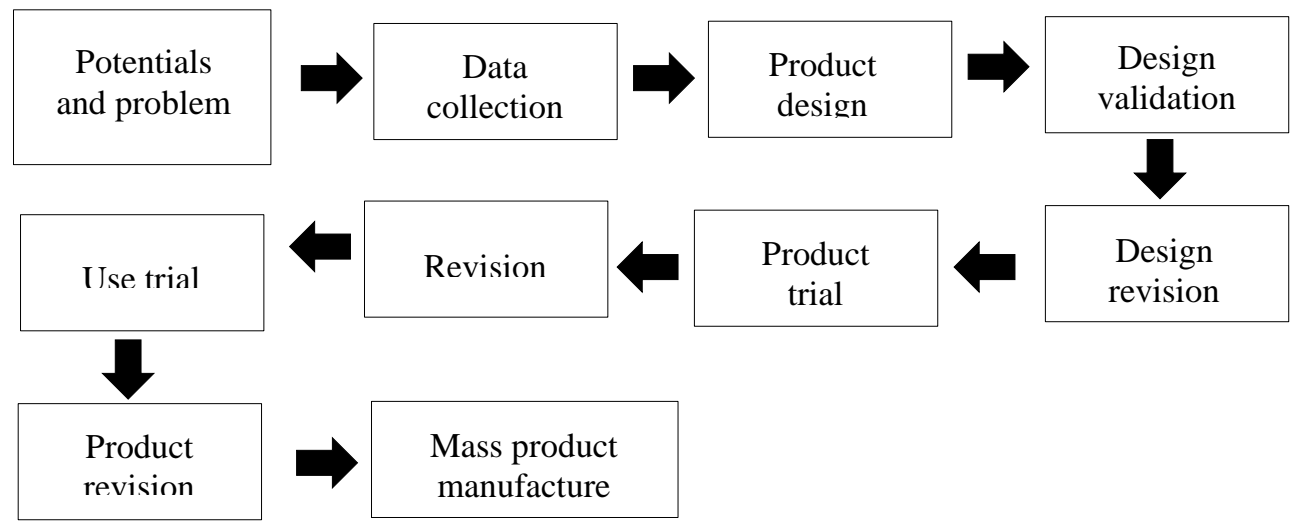

Figure 1. The Schematic of R\&D Method Steps (Sugiyono, 2017)

The software's validity is determined based on the validation results of three validators, namely two chemistry lecturers and one chemistry teacher. The validator provides a software assessment in the form of numbers according to the categories based on Table 1 .

Table 1. Assessment Category

\begin{tabular}{cc}
\hline Scale & Criteria \\
\hline 1 & Very Bad \\
2 & Bad \\
3 & Not Bad \\
4 & Good \\
5 & Very Good \\
\hline
\end{tabular}

Analysis of the validity data is calculating the number of scores based on the Likert scale (Riduwan, 2005). Likert scale is showed in Table 2. The following formula is used to determine the percentage of the results of the validation assessment of each criterion:

$$
\mathrm{P}(\%)=\frac{\text { obtained score }}{\text { maxium score }} \times 100
$$

Media is valid if it gets a percentage of $\geq 61 \%$.

Table 2. Likert Scale (Riduwan, 2005)

\begin{tabular}{cc}
\hline Percentage & Criteria \\
\hline $0 \%-20 \%$ & Invalid \\
$21 \%-40 \%$ & Less \\
$41 \%-60 \%$ & Enough \\
$61 \%-80 \%$ & Valid \\
$81 \%-100 \%$ & Very Valid \\
\hline
\end{tabular}


The software's practicality is determined based on student response questionnaire results and supported by the results of observations of student activities. Analysis data from student response questionnaire and observations of student activities using the Guttman scale by answering "Yes" and "No". Score 1 if "Yes" and score 0 if "No" (Wiyono et al., 2016). Guttman scale in this research is shown in Table 3.

Table 3. Guttman Scale

\begin{tabular}{ccc}
\hline Answer & Positive Question Score & Negative Question Score \\
\hline Yes & 1 & 0 \\
No & 0 & 1 \\
\hline
\end{tabular}

The percentage of "Yes" or "No" answers is calculated using the following formula:

$$
\mathrm{P}(\%)=\frac{\sum \mathrm{F}}{\mathrm{N}} \mathrm{x} 100
$$

Description:

$\mathrm{F}=$ Number of response "Yes" or "No"

$\mathrm{N}=$ Number of students

Media is practical if it gets a percentage of $\geq 61 \%$ based on the interpretation of Likert scale shown in Table 4.

Table 4. Likert Scale (Riduwan, 2005)

\begin{tabular}{cc}
\hline Percentage & Criteria \\
\hline $0 \%-20 \%$ & Very Lack \\
$21 \%-40 \%$ & Less \\
$41 \%-60 \%$ & Enough \\
$61 \%-80 \%$ & Practice \\
$81 \%-100 \%$ & Very Practice \\
\hline
\end{tabular}

The effectiveness of the software is determined based on the results of the conception shift in students. The results of the three-tier diagnostic test are classified according to Table 5.

Table 5. Three-Tier Category (Arslan et al., 2012)

\begin{tabular}{cccc}
\hline Answer & Reason & Confidence level & Criteria \\
\hline True & True & Sure & Know Concept (KC) \\
True & False & Sure & Misconception 1 (M1) \\
False & True & Sure & Misconception 2 (M2) \\
False & False & Sure & Misconception 3 (M3) \\
True & True & Not sure & Don't Know Concept \\
True & False & Not sure & (DKC) \\
False & True & Not sure & \\
False & False & Not sure & \\
\hline
\end{tabular}

The analysis data of the conception shift is calculating the percentage of students' conceptions shift from misconceptions (M), which are based on pretest results, to understanding concepts (KC), which is based on the posttest result. The formula used for the analysis of the shift in the conception of students is as follows: 
Description:

$$
\mathrm{P}(\%)=\frac{\sum \mathrm{M}-\mathrm{KC}}{\sum \mathrm{M} \text { Initial }} \mathrm{X} 100
$$

$\mathrm{P}(\%)=$ The percentage misconception shift

$\Sigma \mathrm{M}-\mathrm{KC}=$ The number of misconceptions shift into know concepts

$\Sigma \mathrm{M}$ Initial $=$ The number of students' who experienced misconceptions at initial Software is effective if the shift in misconceptions to know concept gets a percentage $\geq 61 \%$ based on the interpretation of Likert scale shown in Table 6 .

Table 6. Likert Scale (Riduwan, 2005)

\begin{tabular}{cc}
\hline Percentage & Criteria \\
\hline $0 \%-20 \%$ & Very Lack \\
$21 \%-40 \%$ & Less \\
$41 \%-60 \%$ & Enough \\
$61 \%-80 \%$ & Effective \\
$81 \%-100 \%$ & Very Effective \\
\hline
\end{tabular}

\section{Results and Discussion}

The results of software development using the Research and Development method is described as follows:

\section{Potential and Problem}

Students are very prone to misconceptions, especially in the material that has many abstract concepts, such as stoichiometry. It is supported by various research that shows many students experience misconceptions on stoichiometric material (Djarwo, 2020; Wiwiana et al., 2020; Wulandari \& Rusmini, 2020). Concepts in chemistry are interrelated, so the understanding level of one concept affects others. Misconceptions on one material will impact learning difficulties in other materials, so that it needs to be reduced so the learning objectives can be adequately achieved. Therefore, researcher developed mistion software that can detect and reduce student misconceptions.

\section{Data Collection}

The data collection stage was carried out with a literature study, which shows the number of students had misconceptions about stoichiometric material. Based on research at a high school in Sukoharjo shows that as many as $40.46 \%$ of students experience misconceptions on the concept of reaction equations, $38.36 \%$ of students have misconceptions on the concept of $\mathrm{Ar} / \mathrm{Mr}$, and $53.77 \%$ of students experience misconceptions on the concept of mole (Astuti et al., 2016). Research in a high school in the city of Bandung showed the misconception in the mole concept as many as 46.67\% (Zidny et al., 2015). Meanwhile, research in a high school in Surabaya showed that the misconception occurred in the basic law concept of chemistry at $53.3 \%$, molar mass by $40 \%$, and the number of particles by $53.3 \%$ (Wulandari \& Rusmini, 2020). 
From the different results of these studies, it can be ascertained that misconceptions in stoichiometric material are very prone to occur in students. Therefore, researchers developed mistion software that can detect and reduce misconceptions in stoichiometric material. In this research, there are three subconcepts of stoichiometry that become the focus, namely, the basic law of chemistry, reaction equation, and mole.

\section{Product Design}

The process of making mistion software is carried out using the Adobe Flash Professional CS6 application with action script 3.0. One of the differences between action script 2.0 and action script 3.0 is their script's writing. In action script 2.0, scriptwriting is placed on program objects such as buttons, frames, images, etc., while in action script 3.0, the script is placed in the timeline or class files. The background design and user interface were made using Adobe Illustrator CS6. The mistion software consists of several parts, namely the start page, identity page, instructions, pretest question menu, conceptual change text, and posttest question menu.

Pretest and posttest menu question were made using three-tier test method which is consist of three levels namely, first is the stoichiometric question, second is the reason of the choosing answer, and third is about student's confidence of the choosing answer. There are three sub-concepts of stoichiometric which used in this research, namely basic law chemistry, chemistry reaction equation, and mole. In the pretest, for each sub-concept, a test result will give the student their conception status. If the student gets the result misconception or doesn't know the concept, they are directed to the conceptual change text stage. The conceptual change text is used to fix the students' conception. In this section, students are presented with the conceptual change text stage that must be passed if students detect misconceptions or do not understand the concept. After going through the conceptual change text stage, students will be tested again by posttest questions. In each posttest question, students will get the results of their conception shift.

The mistion software has some advantages to be used as learning media. The advantages are this software is free so that every student can use it, the size of this software is quite small only $10.4 \mathrm{Mb}$, this software doesn't require an internet connection, it is portable for windows 7 until Windows 10, it can be open directly without installing as long as the laptop or PC has adobe flash player, the graphical display of this software is quite attractive, and it also has instruction for users so that they don't confuse to use the software. Some displays of the mistion software are shown in Figure 2. 

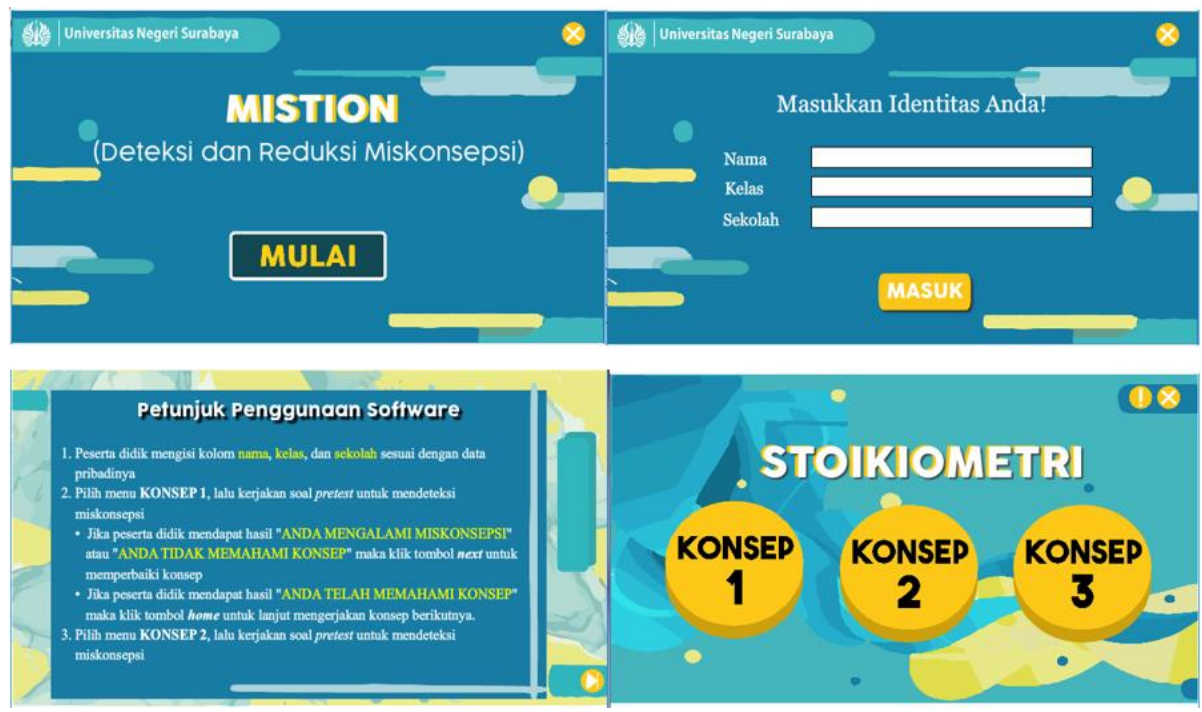

Figure 2. The Display of Mistion Software

\section{Design Validation}

The validation result shows the software's feasibility level based on the results of the average assessment by three validators. There are two types of validation, namely content validation and construct validation. Based on the three validators' assessment result, the average result of the content validation is $93.52 \%$, which is very valid while the average result of construct validation is $91.82 \%$, which is very valid. The content validation result shows that the material, questions, and images presented in the software are suitable with the basic competencies of stoichiometry based on the 2013 revised curriculum with essential basic competencies. The details of the content validation results are shown in Figure 3.

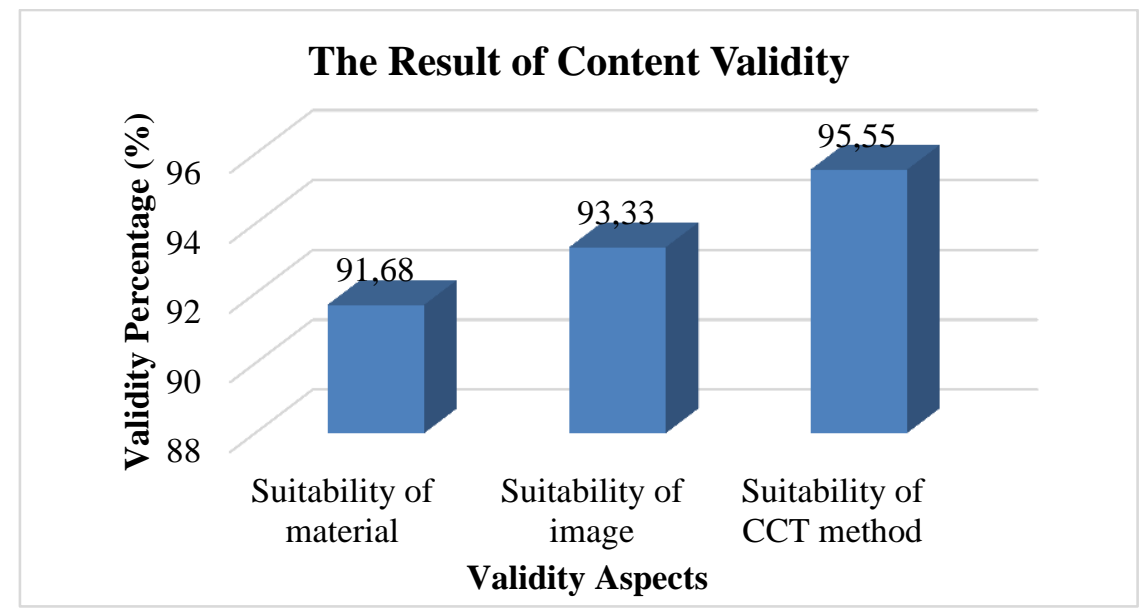

Figure 3. Results of Content Validity

Construct validations' result shows that the language used in the software is suitable with general guidelines for Indonesian spelling, the material presented in the software is complete, and the graphic aspects of the software are very good. The details of the construct validation results are shown in Figure 4. 


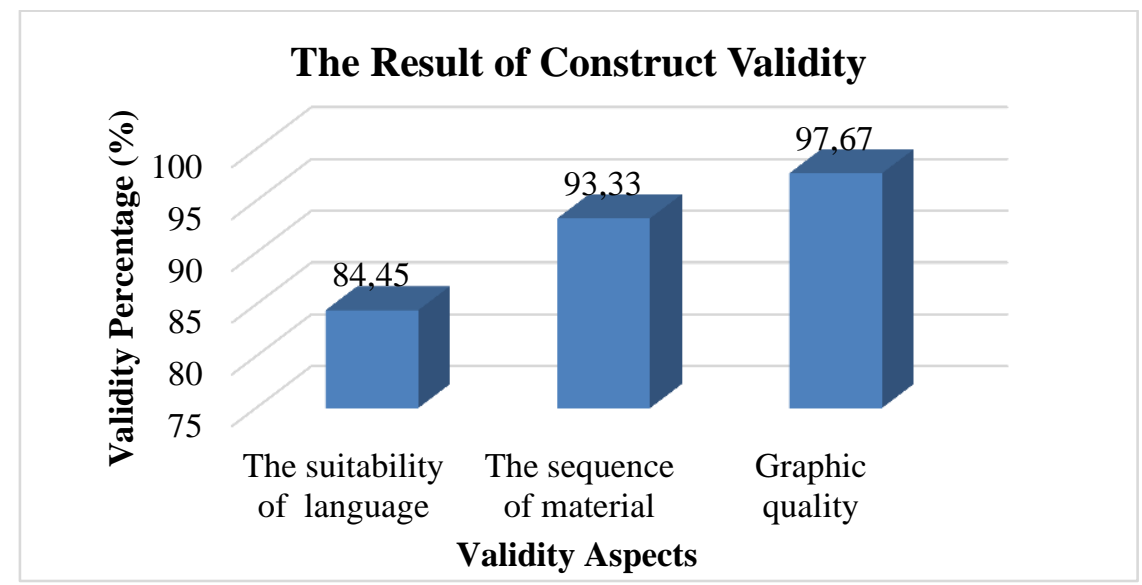

Figure 4. Results of Construct Validity

Based on the content and construct validation results, the mistion software is valid and can be used by students to detect and reduce students' misconceptions.

\section{Design Revision}

After getting the validation results from the validator, the mistion software was revised according to the suggestions given by the reviewer and validator, include 1) Add students' level of doubt about their concept after giving cognitive conflict in software 2) Simplify language in the conceptual change text section of the software, 3) Improve three-tier questions.

\section{Product Trial}

At this stage, the software was tested on 15 students to determine the practicality and effectiveness of the mistion software. The software's practicality is known from the results of student response questionnaires and supported by the results of student observations. Based on the data analysis result, the mistion software gets an average student response questionnaire of $95,28 \%$, which is very practical. The details of the results of the student response questionnaire are shown in Figure 5.

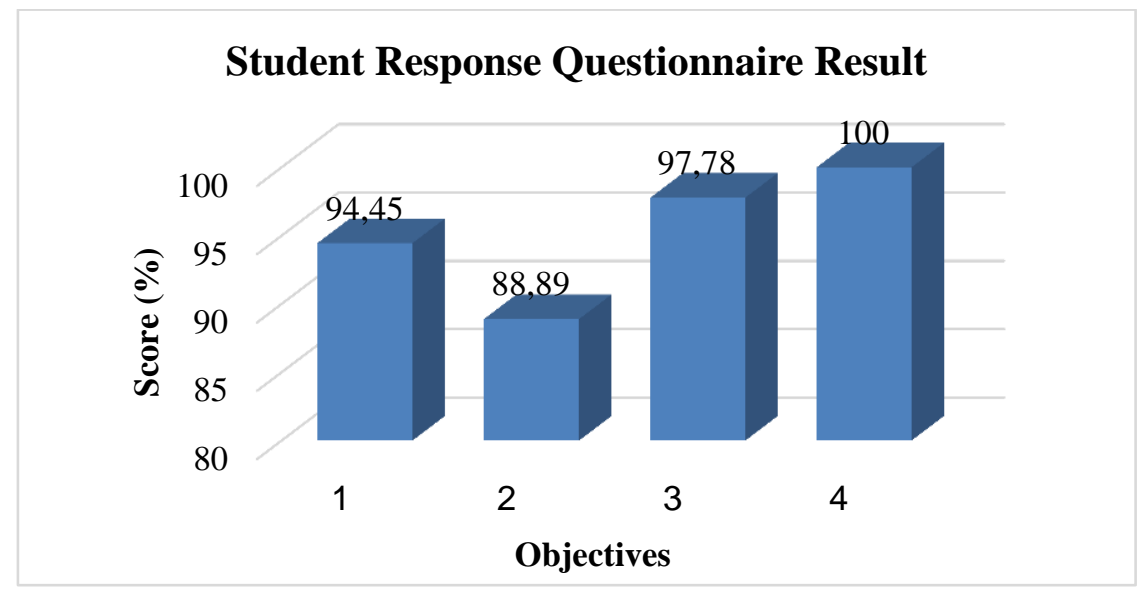

Figure 5. Results of Student Response Questionnaire 
The student response questionnaire consists of four objectives. The first objective is to determine the clarity of the material and its relation to increasing student understanding. This objective gets an average score of $94.45 \%$, which very practical. It proves that the material in the mistion software is easily to understand by students and improves student understanding. The second objective is to determine students' interest in software. The requirement for a good learning media is to motivate students to learn (Shalikhah et al., 2017). This objective gets an average score of $88.89 \%$, which very practical. It proves that students are interested in using mistion software as a learning media. The third objective was to identify the level of ease in using the software. This objective gets an average score of $97.78 \%$, which is very practical. It proves that the mistion software is easy to operate by students. The fourth objective is to determine the clarity of the language used in the software. This objective gets an average score of $100 \%$, which very practical. It proves that all students consider the language used in the software easy to understand, and there are no words that cause multiple interpretations.

The observations of students also support the practicality of the mistion software. Based on the observations result, each objectives' scores range from $66.67 \%$ $100 \%$, with an average score of $85 \%$, which is very practical. The details of the students' observations are shown in Figure 6.

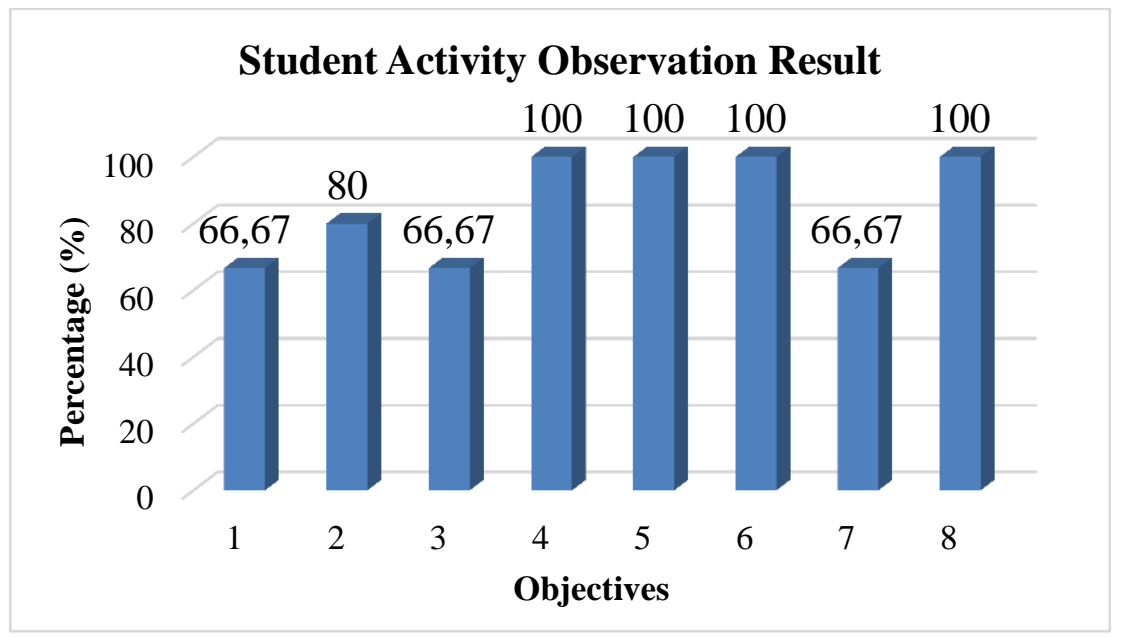

Figure 6. Results of Student Activity Observation

The effectiveness of mistion software is known from students' conception shift result. The initial detection of student misconceptions was carried out through a pretest where the questions were made using three-tier diagnostic tests. The threetier test instrument has the advantage of being able to distinguish between misconceptions and not understanding the concept or not knowing the concept through the confidence level of students' answers, so it is accurate in detecting misconceptions (Peşman \& Eryilmaz, 2010). The results of students' conceptions profile from pretest are shown in Figure 7. 


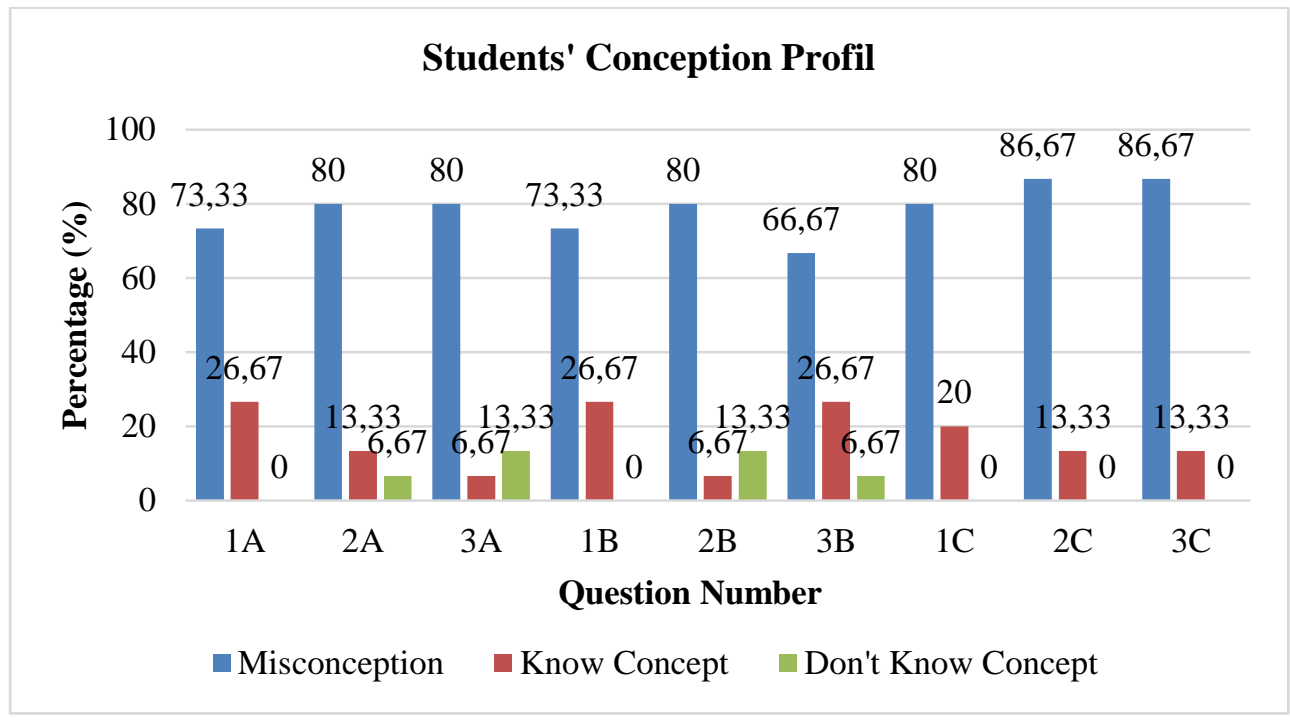

Figure 7. Results of Students' Conception Profile

Based on Figure 7, we know that students' misconceptions were detected in all the questions tested. In the sub-concept of basic chemistry laws, the most misconceptions occurred in question number 2A about Avogadros' Law and 3A about the law of definite proportion. The percentage misconception in question number $2 \mathrm{~A}$ and $3 \mathrm{~A}$ is $80 \%$ or as many as 12 students. In the reaction equations' sub-concept, question number $2 \mathrm{~B}$ about balanced reaction equation was the biggest misconceptions. The percentage misconception in question $2 \mathrm{~B}$ is $80 \%$ or as many as 12 students. In the sub-concept of mole, the most misconceptions occurred in questions $2 \mathrm{C}$ and $3 \mathrm{C}$ about the calculation of mole. The percentage of misconception in question number $2 \mathrm{C}$ and $3 \mathrm{C}$ is $86,67 \%$ or as much as 13 students.

Students who were detected misconceptions, will continue to the conceptual change text stage, which is expected to reduce their misconceptions. Conceptual change text consists of four stages, namely (1) showing students 'conceptions, (2) creating cognitive conflicts, (3) equilibrating processes, and (4) reconstructing students' concepts (Sendur \& Toprak, 2013). Concept change will occur when students are faced with an unbalanced state, that is incompatibility between the concepts they have and the surrounding environment, causing conflict in their minds (Pebrianti et al., 2015). One way to raise the dissatisfaction is by presenting an anomalous event, which is an event that is contrary to the concept of the student (Pebrianti et al., 2015). In the mistion software to cause cognitive conflict in students is done by asking questions with anomalous data. There are choices about the level of conceptual doubt in software to ensure that students experienced cognitive conflict. Data for the level of hesitate on students' concepts can be seen in Figure 8. 


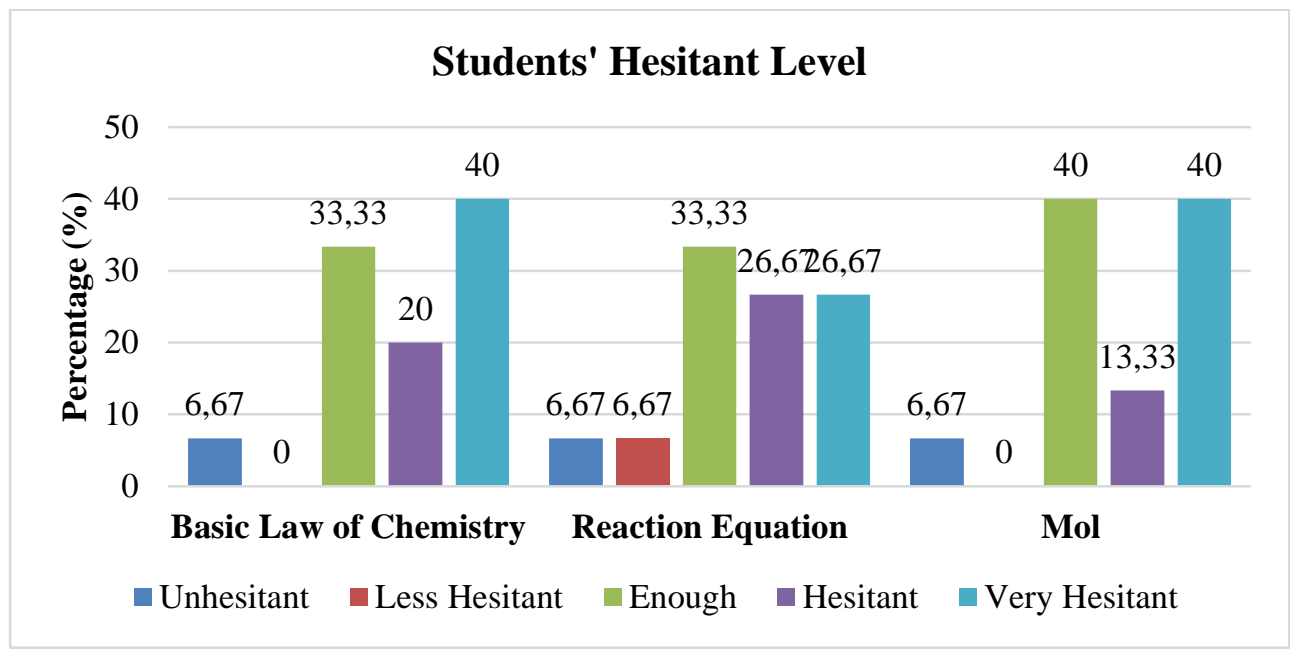

Figure 8. Results of Students' Conception Profil

Based on Figure 8, we knew that as much as $40 \%$ or equivalent to 6 students is very hesitant about their basic law of chemistry concept, as much as $33,33 \%$ or equal to 5 students is hesitant enough about their reaction equation concept, and as much as $40 \%$ or equivalent to 6 students is very hesitant about their mole concept.

After going through the conceptual change text stage, students proceed to the posttest stage to find out the shift in their conceptions. The detailed results of students' conception shift are shown in Table 7.

Table 7. The Result of Conception Shift

\begin{tabular}{|c|c|c|c|c|c|c|c|c|c|c|c|c|c|}
\hline \multirow[t]{2}{*}{ No } & \multirow[t]{2}{*}{$\begin{array}{l}\text { Conce } \\
\text { ption } \\
\text { Shift }\end{array}$} & \multicolumn{3}{|c|}{$\begin{array}{c}\text { Basic Law } \\
\text { of } \\
\text { Chemistry }\end{array}$} & \multirow[t]{2}{*}{ Total } & \multicolumn{3}{|c|}{$\begin{array}{l}\text { Reaction } \\
\text { Equation }\end{array}$} & \multirow[t]{2}{*}{ Total } & \multicolumn{3}{|c|}{ Mole } & \multirow[t]{2}{*}{ Total } \\
\hline & & 1 & 2 & 3 & & 1 & 2 & 3 & & 1 & 2 & 3 & \\
\hline 1 & $\mathrm{M}-\mathrm{KC}$ & 9 & 9 & 9 & 27 & 9 & 10 & 9 & 28 & 9 & 11 & 8 & 28 \\
\hline 2 & $\begin{array}{l}\text { M- } \\
\text { DKC }\end{array}$ & 0 & 0 & 2 & 2 & 0 & 0 & 0 & 0 & 0 & 0 & 0 & 0 \\
\hline 3 & M-M & 2 & 3 & 1 & 6 & 2 & 2 & 1 & 5 & 3 & 2 & 5 & 10 \\
\hline 4 & $\begin{array}{l}\text { DKC- } \\
\text { KC }\end{array}$ & 0 & 1 & 2 & 3 & 0 & 2 & 1 & 3 & 0 & 0 & 1 & 1 \\
\hline 5 & $\begin{array}{l}\text { DKC- } \\
\text { DKC }\end{array}$ & 0 & 0 & 0 & 0 & 0 & 0 & 0 & 0 & 0 & 0 & 0 & 0 \\
\hline 6 & $\begin{array}{l}\text { DKC- } \\
\mathrm{M}\end{array}$ & 0 & 0 & 0 & 0 & 0 & 0 & 0 & 0 & 0 & 0 & 0 & 0 \\
\hline 7 & KC-KC & 4 & 2 & 1 & 7 & 4 & 1 & 3 & 8 & 3 & 2 & 0 & 5 \\
\hline 8 & $\begin{array}{l}\text { KC- } \\
\text { DKC }\end{array}$ & 0 & 0 & 0 & 0 & 0 & 0 & 0 & 0 & 0 & 0 & 0 & 0 \\
\hline 9 & KC-M & 0 & 0 & 0 & 0 & 0 & 0 & 1 & 1 & 0 & 0 & 1 & 1 \\
\hline
\end{tabular}

The results of the misconception shift percentage $(\mathrm{M}-\mathrm{KC})$ are presented in Figure 9. 


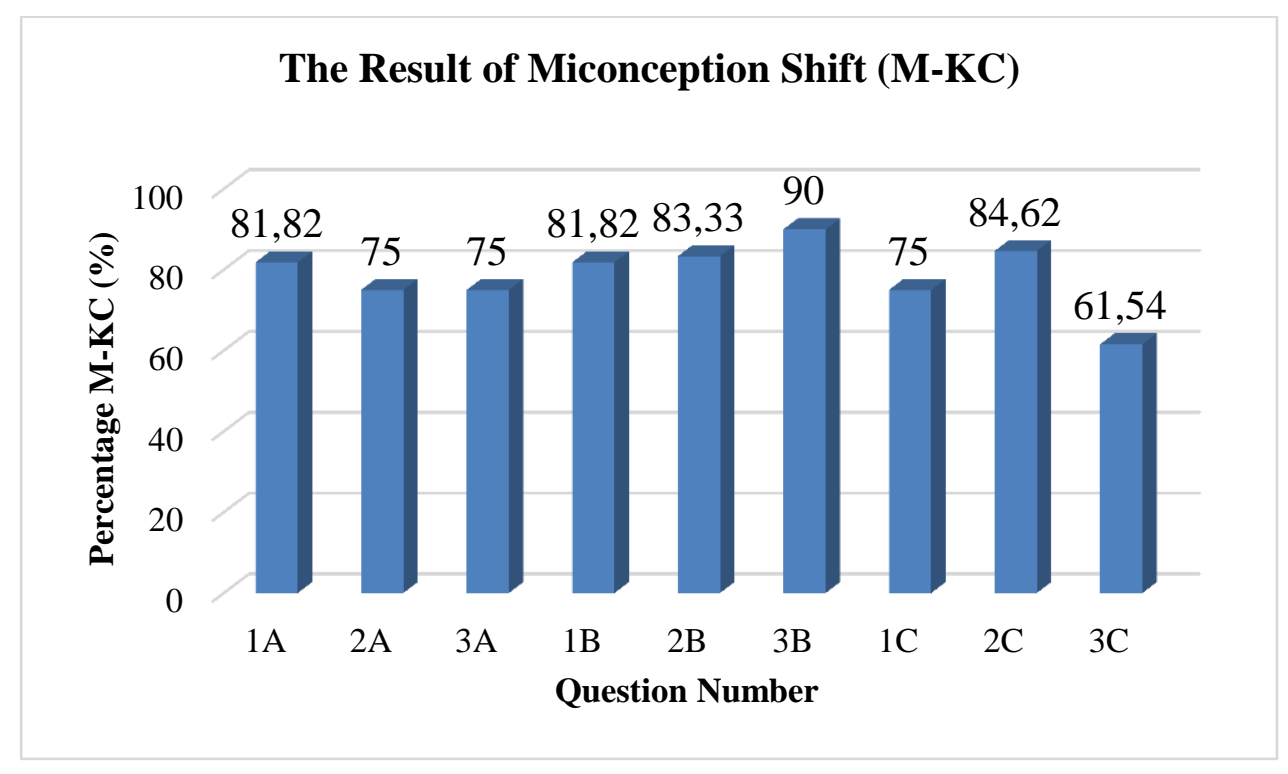

Figure 9. Results of Miconception Shift (M-KC)

Based on Table 7 and Figure 9, it is known that for sub-concept basic law of chemistry, in question number 1 , the student misconceptions shift from initially misconceptions to understand concepts (M-KC) were as many as 9 out of 11 students with a percentage of $81.82 \%$. In question number 2 , the student misconceptions shift from initially misconceptions to understand concepts (M$\mathrm{KC})$ were as many as 9 out of 12 students with a percentage of $75 \%$. Then, in question number 3 , the student misconceptions shift from initially misconceptions to understand concepts (M-KC) were as many as 9 out of 12 students with a percentage of $75 \%$. The lowest percentage is in question 2 about Avogadro's Law and question 3 about the definite proportion law. In the concept of definite proportion law, students assume that the reagent with the least mass is used as a determinant of the calculation. The correct calculation should involve the mass ratio of the constituent elements (Anugrah, 2013). Then, in Avogadro's law, students assume that the gases with the same volume have the same mass at the same temperature and pressure. Supposedly, the mass of gases is different depending on the molar mass.

The sub-concept of reaction equation, for question number 1, the student misconceptions shift from initially misconceptions to understand concepts (MKC) were 9 out of 11 students with a percentage of $81.82 \%$. In question number 2 , the student misconceptions shift from initially misconceptions to understand concepts (M-KC) were as many as 10 out of 12 students with a percentage of $83.33 \%$. Then, in question number 3 , the student misconceptions shift from initially misconceptions to understand concepts (M-KC) were as many as 9 out of 10 students with a percentage of $90 \%$. The lowest percentage is in question number 1 about the balanced equation reaction. Students assume that a balanced chemical reaction's coefficient must be the same in right and left sides. The correct concept is balanced chemical reaction has the same number of an atom in the right and left side. 
Then, the sub-concept of mole, in question number 1, the student misconceptions shift from initially misconceptions to understand concepts (M-KC) were as many as 9 out of 12 students with a percentage of $75 \%$. In question number 2 , the student misconceptions shift from initially misconceptions to understand concepts (M-KC) were as many as 11 out of 13 students with a percentage of $84.62 \%$. Then, in question number 3, the student misconceptions shift from initially misconceptions to understand concepts (M-KC) were as many as 8 out of 15 students with a percentage of $61.54 \%$. The lowest misconception shift occurs in question number 3 about the relationship between volume and mole of a gaseous substance. Students who detected misconceptions in this question assume that gases which have the same volume have the same number of moles and particles according to Avogadro's Law but actually it only applies when the gases at the same temperature and pressure. The correct concept is gas with the same volume but at different temperatures and pressures have different numbers of particles and moles gas. The greater the pressure, the greater the number of moles and the number of gas particles. The misconception that occurs in the conversion of moles to volume is that students cannot distinguish the use of the formula PV $=n R T$ with the formula $\mathrm{V}=22.4 \mathrm{x}$ n (Anugrah, 2013).

Based on the posttest results that have been carried out, the shift in the conceptions of students from misconceptions to knowing the concepts in the basic chemical law sub-concepts is $77.27 \%$ in the effective category, the reaction equation sub-concept is $85.05 \%$ is in the very effective category and the mole subconcept is $73.72 \%$ in the effective category. The results of misconception shift in all questions can be seen in Figure 9.

\section{Conclusion}

Based on the results of the study, it can be concluded that the validity of the software in terms of content and construct validity is in the very valid category. The mistion software's practicality is in the very practical category based on the result of student response questionnaires and supported by the result of student observations. Then, the mistion software's effectiveness is known from misconceptions shift of basic chemical law which get effective category, reaction equation which get very effective category, and mole which get effective category. So, the mistion software is feasible to reduce and detect students' misconception.

\section{References}

Adadan, E. (2013). Using Multiple Representations to Promote Grade 11 Students' Scientific Understanding of the Particle Theory of Matter. Research in Science Education, 43(3), 1079-1105.

Alhinduan, S. S. R., Kurniawan, Y., \& Muliyani, R. (2016). Identifikasi Kuantitas Siswa yang Miskonsepsi Menggunakan Three Tier-Test pada Materi Listik Dinamis. JIPF (Jurnal Ilmu Pendidikan Fisika), 1(1), 29-31. 
Anintia, R., Sadhu, S., \& Annisa, D. (2017). Identify Students' Concept Understanding Using Three-Tier Multiple Choice Questions (TTMCs) on Stoichiometry. International Journal of Science and Applied Science, 2(1), 308-317.

Anugrah, I. R. (2013). Mengungkap Miskonsepsi Topik Stoikiometri Pada Siswa Kelas X Melalui Tes Diagnostik Two-Tier [Indonesian Education University]. http://repository.upi.edu/1630/

Arslan, H. O., Cigdemoglu, C., \& Moseley, C. (2012). A Three-Tier Diagnostic Test to Assess Pre-Service Teachers' Misconceptions about Global Warming, Greenhouse Effect, Ozone Layer Depletion, and Acid Rain. International Journal of Science Education, 34(11), 1667-1686.

Astuti, F., Redjeki, T., \& Nurhayati, N. D. (2016). Identifikasi Miskonsepsi dan Penyebabnya pada Siswa Kelas Xi Mia SMA Negeri 1 Sukoharjo Tahun Pelajaran 2015/2016 Pada Materi Pokok Stoikiometri. Jurnal Pendidikan Kimia, 5(2), 10-17.

Djarwo, C. F. (2020). Analisis Reduksi Miskonsepsi Mahasiwa Setelah Penerapan Model Pembelajaran ECIRR pada Materi Stoikiometri. Jurnal Ilmu Sosial Dan Pendidikan, 4(3), 567-573.

Fitria, Priatmoko, S., \& Kasmui. (2016). Penggunaan Multimedia Interaktif dalam Meminimalisasi Miskonsepsi Siswa pada Materi Pokok Larutan Penyangga. Jurnal Inovasi Pendidikan Kimia, 10(1), 1641-1650.

Kurniasih, L. (2013). Peranan Teks Perubahan Konseptual Terhadap Pemahaman Konsep Siswa SMA Kelas XI Pada Materi Hidrolisis Garam [Indonesian Education University]. http://repository.upi.edu/2473/

Made Rajendra, I., \& Made Sudana, I. (2017). The Influence of Interactive Multimedia Technology to Enhance Achievement Students on Practice Skills in Mechanical Technology. Journal of Physics: Conference Series, 953(1), 1-5.

Mashami, R. A., Andayani, Y., \& Gunawan, G. (2014). Pengaruh Media Animasi Submikroskopik Terhadap Peningkatan Kemampuan Representasi Siswa. Jurnal Kependidikan Kimia, 2(1), 149-152.

Nikmawati, U., Refelita, F., \& Yasthophi, A. (2019). Komparasi Sturcture Exercise Method dan Drill Terhadap Pemahaman Konsep pada Materi Stoikimetri. Konfigurasi, 3(1), 8-14.

Pebrianti, D., Sahidu, H., \& Sutrio. (2015). Efektifitas Model Pembelajaran Perubahan Konseptual untuk Mengatasi Miskonsepsi Fisika pada Siswa Kelas X SMAN 1 Praya Barat Tahun Pelajaran 2012/2013. Jurnal Kependidikan Fisika Dan Teknologi, 1(1), 92-96.

Peşman, H., \& Eryilmaz, A. (2010). Development of a Three-Tier Test to Assess Misconceptions About Simple Electric Circuits. Journal of Educational Research, 103(3), 208-222.

Putri, P. C., Fitriadini, A., Khalid, L., \& Isnainiyah, I. N. (2020). Prototype Pembelajaran Interaktif Unsur Kimia Menggunakan Augmented Reality. Seminar Nasional Mahasiswa Ilmu Komputer Dan Aplikasinya, 1(1), 545553.

Riduwan. (2005). Skala Pengukuran Variabel-Variabel Penelitian. Bandung: Alfabeta.

Sadiqin, I. K., Istyadji, M., \& Winarti, A. (2017). Mengoptimalkan Potensi Otak 
Kanan Siswa dalam Pembelajaran Kimia. Jurnal Inovasi Pendidikan Sains, 8(1), 27-35.

Sendur, G., \& Toprak, M. (2013). The Role of Conceptual Change Texts to Improve Students' Understanding of Alkenes. Chemistry Education Research and Practice, 14(4), 431-449.

Shalikhah, N. D., Primadewi, A., \& Iman, M. S. (2017). Media Pembelajaran Interaktif Lectora Inspire sebagai Inovasi Pembelajaran. Warta LPM, 20(1), 9-16. https://doi.org/10.23917/warta.v19i3.2842

Sugiyono. (2017). Metode Penelitian Kuantitatif, Kualitatif dan R\&D. Bandung: Alfabeta.

Sutinah, \& Sigit, D. (2018). Efektivitas Penerapan Modul Stoikiometri Berdasarkan Konsep Sukar dan Kesalahan Konsep pada Pemahaman dan Persepsi Peserta Didik Kelas X SMA. Jurnal Pendidikan:Teori, Penelitian, Dan Pengembangan, 3(8), 990-993.

Wiwiana, Hasri, \& Husain, H. (2020). Analisis Miskonsepsi Peserta Didik Menggunakan Certainty of Response Index (CRI) pada Materi Stoikiometri. Chemistry Education Review, 4(1), 10-15.

Wiyono, F. M., Sugiyanto, S., \& Yulianti, E. (2016). Identifikasi Hasil Analisis Miskonsepsi Gerak Menggunakan Instrumen Diagnostik Three Tier pada Siswa SMP. Jurnal Penelitian Fisika Dan Aplikasinya (JPFA), 6(2), 6169.

Wulandari, C. A., \& Rusmini. (2020). Pengaruh Penggunaan LKPD dengan Model Pembelajaran ECIRR dalam Mereduksi Miskonsepsi pada Materi Stoikiometri Kelas X SMA. Jurnal Pendidikan Kimia, 4(1), 1-15.

Zidny, R., Sopandi, W., \& Kusrijadi, A. (2015). Gambaran Level Submikroskopik untuk Menunjukkan Pemahaman Konsep Siswa pada Materi Persamaan Kimia dan Stoikiometri. Jurnal Penelitian Dan Pembelajaran IPA, 1(1), $42-59$.

How to cite this article:

Prastika, R. A., \& Sukarmin. (2021). Development of MISTION Software to Detect and Reduce Students' Misconception with Conceptual Change Text Strategy on Stoichiometry Materials. Journal of Educational Sciences, 5(3), 423-438. 